\title{
ANALYSIS OF THE PUBLIC TRANSPORT PROVISION IN SUCEAVA-BOTOȘANI URBAN AREA (ROMANIA)
}

\author{
Marian lonut ISTRATE \\ University of Bucharest, "Simion Mehedinți" Doctoral School, \\ Faculty of Geography, Romania
}

\begin{abstract}
Having a major economic and social role, public transport is an important component in the process of sustainable development of a city. The paper aimed to study the public transport at metropolitan and regional scale evidencing how two major urban centers of Romania, Suceava and Botosani, connect via public transport with the rural settlements in their metropolitan areas. The metropolitan supply of public transport was analysed starting with publicly available data on the routes in 2014 for both Botosan County and Suceava County, located in the North-Eastern side of Romania. The routes spatial disposition and daily frequency is analysed for road and rail public transport. The resulted mappings showed that road public transport is well distributed in the metropolitan territory for both urban centres, but there is still almost $4 \%$ of the rural population that does not have direct access to this public utility service. The rail public transport covers only a small amount of the studied area and it has a secondary role in supplying public transport services for the population because of the lack of investments that the entire rail secto suffered in Romania. The share of private cars has increased significantly, but the population's need for mobility is not completely covered and this paper offers some recommendations for the improvement of the public transportation supply in SuceavaBotoșani Urban Area.
\end{abstract}

Key Words: metropolitan public transport, public transport provision, accessibility, Suceava-Botoșani Urban Area, Romania.

\section{Introduction}

A city's accessibility is vital for its path in the global city competition as the services that it hosts must be in reach for the people than depend on it, either those services are educational, medical, or related to the provision of general or specific goods, jobs and many others. In this context, public transport is the best solution to ensure the mobility of the population, because it is an environmental friendly mode of transport and especially, as it is the case of Romania, because it represents a social service, being a cheaper alternative to private cars, thus more affordable for the low-income and medium class citizens (Lucas 2004).

Public transport (PT) is an important field of the transport industry in Romania, while urban PT and interurban PT have suffered a major decrease in usage and the quality of services (Fistung et al. 2004, lordache 2009, Rădulescu et al. 2013). Also, the continuing decline of rail transport has brought the focus on the road public transport, which is cheaper and more flexible. Transportation and public transport constitute a framework and not a product (European Spatial Planning Observation Network 2004) while a good supply of PT services can bring positive externalities for the core city and for the communities that benefit from the good provision (Ong and Evelyn 1997, Sanchez et al. 2004, Rotem-Mindali and Gefen 2014).

The proper management of public transport takes into consideration the demand-supply relationship. There is a vast literature that researches how demand can be analysed and which focuses on the social characteristics of the people that can choose PT as a mode to commute (Kanafkani 1983, Oum et al. 1992, Pinjari and Bhat 2011) together with the economic state of a city or of a neighbourhood (Bresson 2004). In order to assess the demand for PT, statistical 
data regarding the user and his location must be analysed (gender, age, employment status, income, car ownership, city size, population density, and urban versus rural location) together with the purpose of the trips (trips to work, school, for shopping, recreation, visiting friends and family) (Buehler and Pucher 2012). This paper does not cover the demand analysis for PT in the studied area, because complete and detailed needed data are not available at the used territorial scale.

Researchers consider demand more important than the supply of PT because demand comes first and it models the supply's characteristics. Many authors are researching ways to better understand the demand in order to provide better PT services. A good provision is marked by the ratio between good frequencies and economic sustainability. An analysis of the geographical coverage of the metropolitan and regional PT can provide valuable inputs for the policies that shape the provision of this type of services so that planners can adopt strategies for improving the accessibility and optimizing the PT (Murray 2001).

This paper studies the provision of metropolitan, county-level and regional road and rail public transport for the metropolitan areas of the cities of Suceava and Botoșani. In the first part of the paper, the studied area, the data sources and the methodology of the research are presented, followed then by the results of the research, first for road PT and after for rail PT. Some data regarding car ownership is presented and at the end, the conclusions and some recommendations for improving the provision of PT in the studied area are given.

\section{Materials and methods}

The study area is comprised of the two metropolitan areas belonging to two middle-sized cities - Suceava and Botoșani - situated in the North Eastern side of Romania. These cities developed together an associative form of governance called Suceava-Botosani Urban Area (Fig. 1). This territorial association, gathering 30\% (314 637 inhabitants in 2011) of the respective counties' total population and $50 \%$ of their urban population (212 257 inhabitants), includes 4 cities, of which 2 are municipalities, and 20 communes that have together 89 villages. Suceava-Botoșani Urban Area occupies 9\% (1212.1 sq. km) of the total area of Botosani and Suceava counties and the built-up area has a share of $11 \%$ of its total surface. Being an association to which members adhere voluntarily, a commune located near Suceava chose not to be a part of this organization due to political reasons, despite the fact that it has a significant role in the Suceava Metropolitan Area. This commune was included in the study area. The Inter -Community Development Association's goal is to make Suceava-Botoșani Urban Area the "most dynamic urban area at the eastern EU border, an economic, cultural and touristic competitive pole, accessible, sustainable and inclusive, attractive for its inhabitants, for tourists and investors, with an efficient governance and active and involved citizens" (Botoșani County Council 2015: 168).

The inter-city road PT is planned by the counties' councils which set the routes, the intermediary stations, the frequencies, the timetables, the required capacity of buses, being the same system as it is in Sweden (Jannson 1993) or in London (Amaral et al. 2009). After this process is completed, the related data are introduced in an IT platform called „Informatics system for electronic assignment of freight transport permits and for electronic assignment of the national routes of regular passenger transport services for counties and inter-counties" (acronym S.A.E.T., in Romanian) which is in the attribution of a governmental agency. This platform is an auction system where the counties' councils introduce the named parameters and the private passenger operators can bid for the desired routes while the winner of a route is assigned according to a methodology established by law. Also, the firms that win the bids must get a transport license from the counties' administration. The established program of the county public transport is available for 5 years but the county's administration can modify it by introducing new routes, or by modifying the frequencies, the timetable or the 
transportation capacity of certain routes. The city of Suceava is the administrative residence of Suceava County and the city of Botoșani is the administrative residence of Botoșani County, therefore, when it comes to planning the county and regional public transport we have two distinct bodies that decide which bus goes where and how many times in a day.

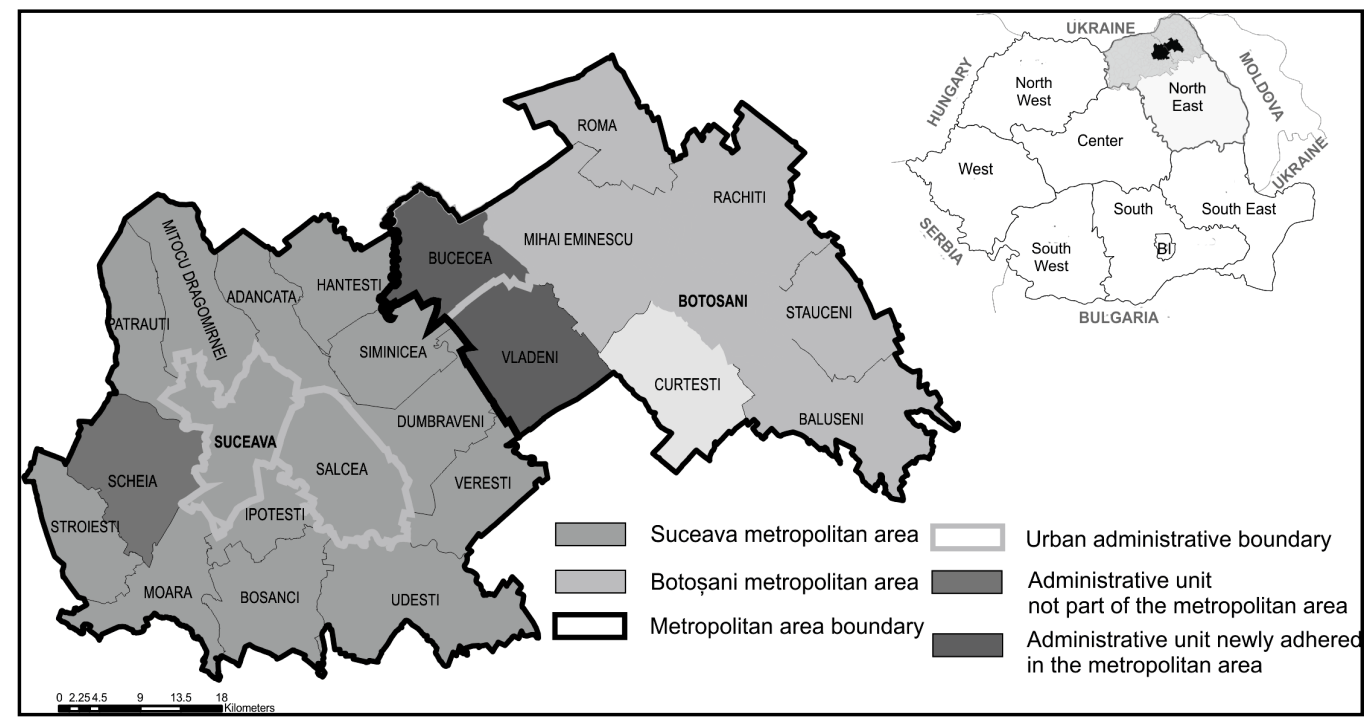

Fig. 1 - The localization and the administrative components of uceava-Botoșani Urban Area

The data sources for the metropolitan road PT are the publicly available data hosted by the portal data.gov.ro, a governmental open data portal, where there is available the nationwide information regarding the county and inter-counties PT. This data was confronted with the information found on the internet page of the County Council of Suceava and the County Council of Botoșani. After some tweaks, the spreadsheet was GIS compatible. After all the routes were mapped in ArcGIS (Fig. 2), using the Network Analyst tool, they were split at the intersections of the road network and the resulted segments had the cells that contained the attribute with the number of routes added, so that each road segment now had an attribute with the number of daily routes that is transited.

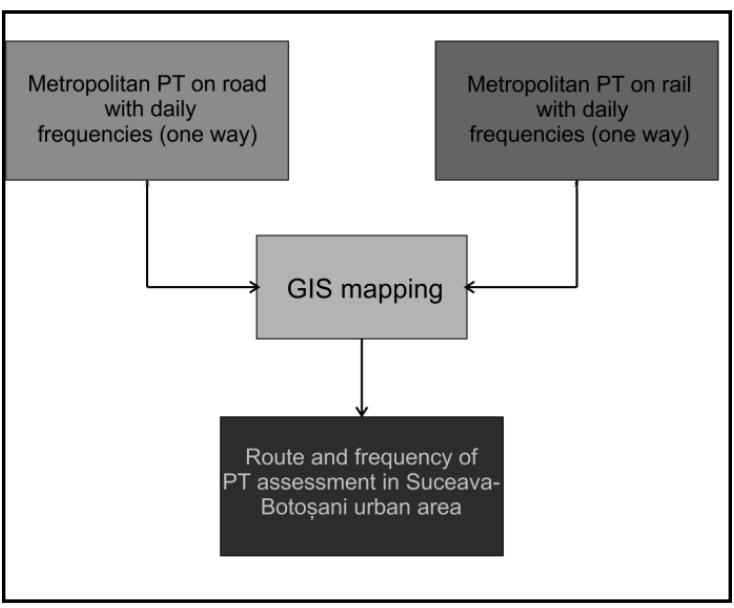

Fig. 2 - The methodological approach of the research The road PT routes are for 2014-2019 period.

The same approach was used for mapping the rail transport; the difference for the rail mode is that they are operated by a single company - the National Railway Passenger Transportation 
Company "C.F.R. Călători S.A.", which provides on its website the timetable and statistic information for the stations. For rail public transport, the timetable for 2015-2016 period was used.

\section{Results and discussion}

The current assessment of the PT supply in the Suceava-Botoșani Urban Area has the same accuracy as the data that were used for the analysis. However, the research showed that not all the routes that are in the cited data sources are actually operated and in some cases the daily frequencies are lower than in the official documents while, most often, the capacity of a route is lower in reality than it was required at the auction to implement it. These inconsistencies were discovered during the field research and they make the assessment presented in this paper to be not $100 \%$ accurate. Also, it must be taken into consideration that the routes suffer permanent changes, at the initiative of local authorities or private entities. Another matter that influenced the final results is that the mapping included the routes between Suceava and Botoșani and other major cities in Romania because, in the majority of cases, they provide public transport services for the settlements near their origin and destination, and therefore act as a metropolitan PT provider. The number of these routes is not so high while only a few trips per day are made.

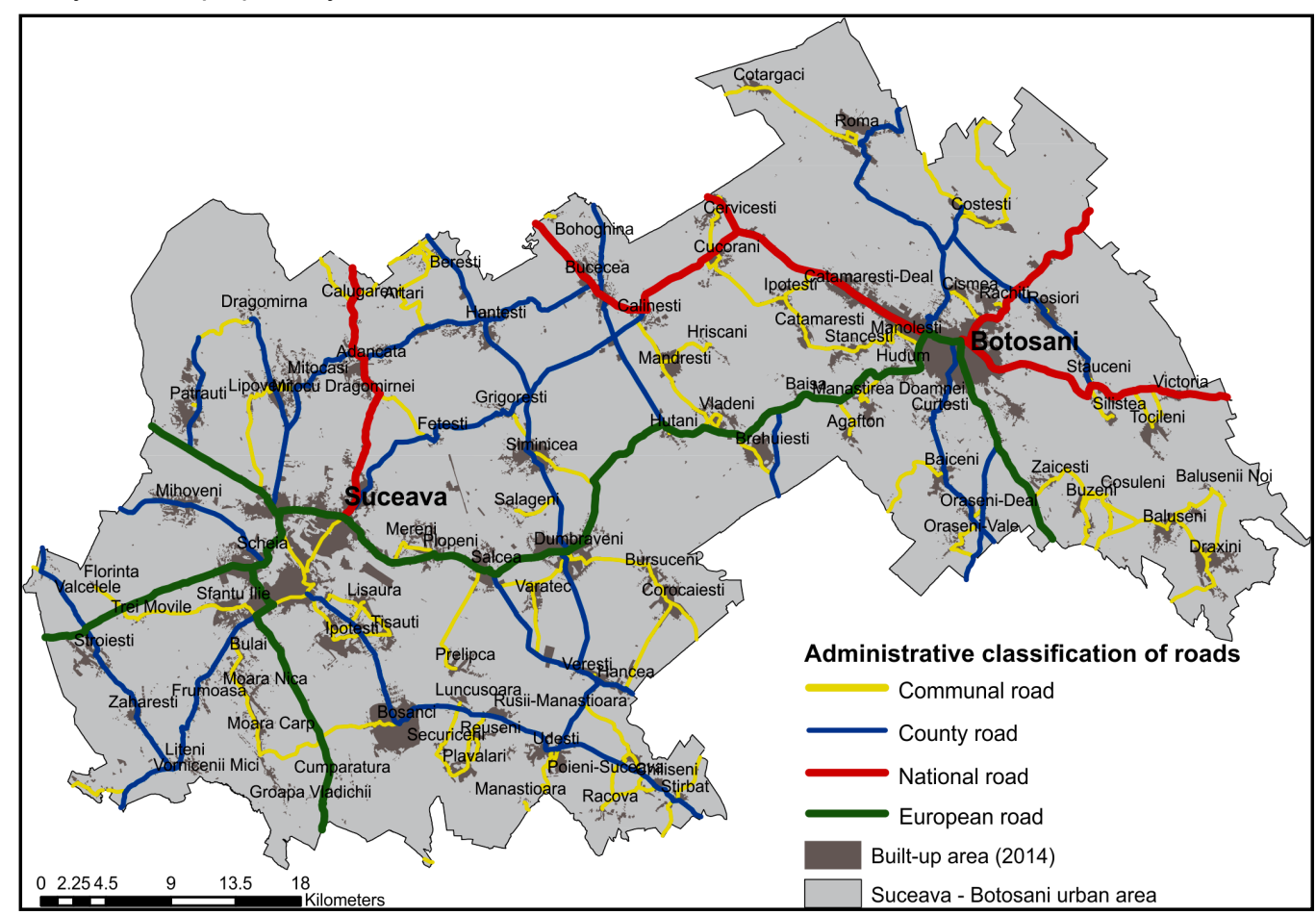

Fig. 3 - The administrative classification of public roads in Suceava-Botoșani Urban Area

The mapping was done using the public road network from the studied area (Fig. 3), which is quite dense in roads $(54 \mathrm{~km} / 100 \mathrm{sq}$. $\mathrm{km}$.), while the average density in Romania is only 34 $\mathrm{km} / 100 \mathrm{sq}$. km (National Institute of Statistics 2013). The mapped geographical distribution of the road PT in the studied area is shown in Figure 4. 


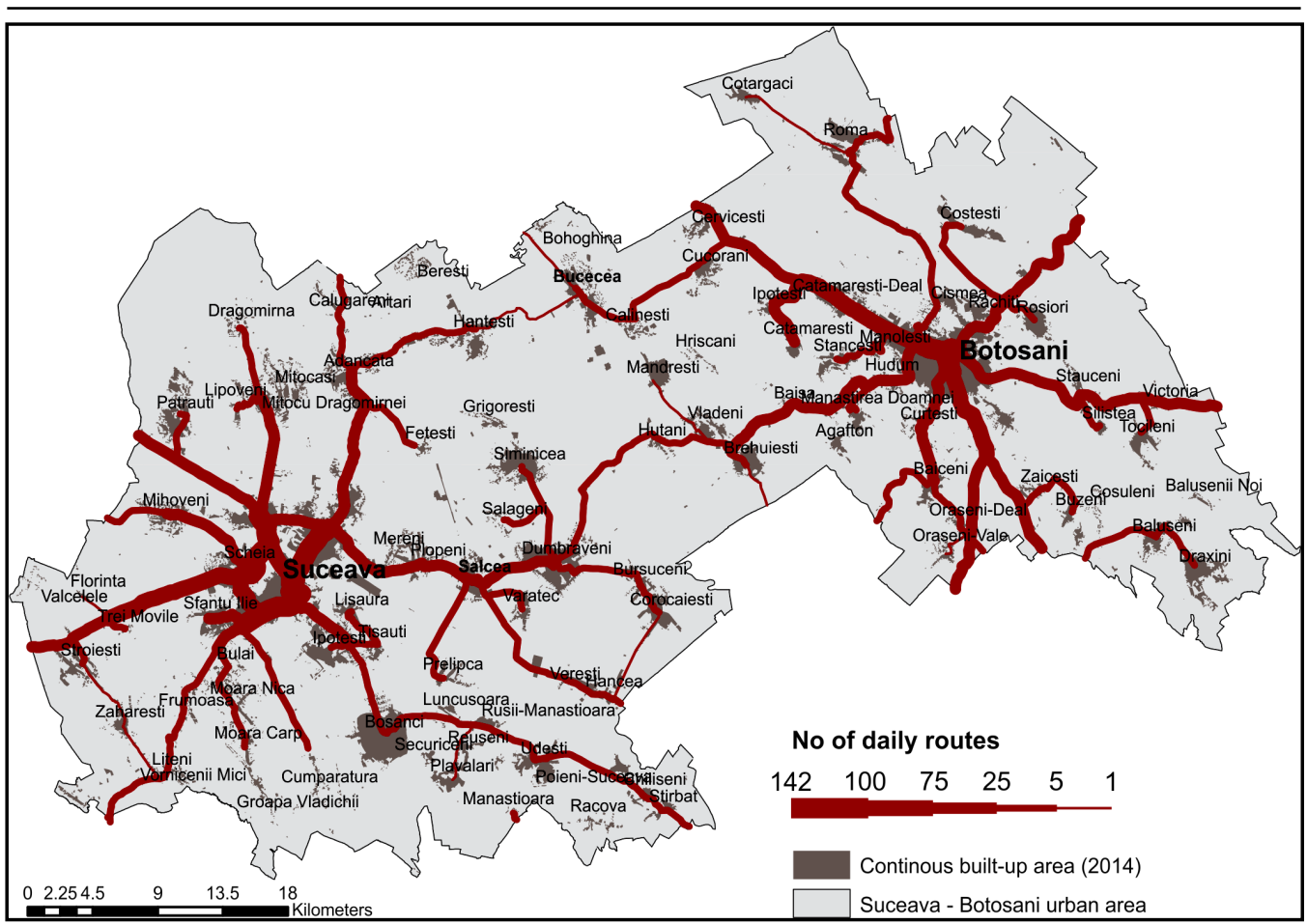

Fig. 4-The geographical distribution and daily frequency of metropolitan public transport in Suceava-Botoșani Urban Area

The mapping shows that there is a clear delimitation between the two transport systems, given the fact that the PT is planned separately by two administrations, while the distinct role that each city is holding in its territorial system becomes obvious. Botoșani and Suceava are the main cities in their counties and PT is planned accordingly, the origin of the majority of bus lines being in these two cities.

The PT system is not planned as a metropolitan system, but as a county system while the fact that good frequencies are assured for the journeys inside the metropolitan area is due to the proximity of the main city. Also, the topology of the network makes a settlement to be transited by more routes (von Ferber et al. 2009, Abundo et al. 2013). Most of the routes with high frequency connect the two administrative residences with the other cities in the county, but there are some routes that confer to these systems a metropolitan particularity. There are a significant number of routes that are short in distance, but have a very high frequency. For example, the highest frequency in Botoșani metropolitan area is for the route Botoșani-IpoteștiCătămărăști, a route that is only 8-kilometers-long but that has a frequency of 31 buses per day in one way. For the case of Suceava metropolitan area, the route Sfântu Ilie-Ițcani-Pătrăuți can be mentioned, having 15 kilometres in length and a frequency of 23 buses per day in one way. The frame network for road PT influences the number of transits, the national and European roads being the most utilized roads that are transited by the regional and metropolitan PT.

The road PT connection between the two major cities is surprisingly weak, being of only 21 one way. These daily routes connect the two cities that both have more than 100.000 inhabitants and that are at a distance of $40 \mathrm{~km}$. from each other. From the data analysis of these routes, 
only 7 of them are in direct connection (for Suceava-Botoșani strictly), the rest of them having different end lines, while Suceava is a transit point for all the routes that go from Botoșani to the western part of the country (to big cities like Cluj-Napoca or Timișoara).

Inside the metropolitan areas, the PT links between the urban settlements are quite good, as Suceava and Salcea are linked with 75 daily one-way routes and Botoșani and its urban neighbour, Bucecea, are linked with 14 daily one-way routes (Table 1). Very few or no links are between the small towns and between small towns and the residence of the other county, which means that the flows between these nodes are very low, and that the small towns are dependent mostly on their major city.

The number of direct road PT links between the cities of the studied area

Table 1

\begin{tabular}{|c|c|c|c|c|}
\hline & Suceava & Botoșani & Bucecea & Salcea \\
\hline Suceava & 0 & 21 & 1 & 75 \\
\hline Botoșani & 21 & 0 & 14 & 21 \\
\hline Bucecea & 1 & 14 & 0 & 0 \\
\hline Salcea & 75 & 21 & 0 & 0 \\
\hline
\end{tabular}

When it comes to which companies operate these networks, there are 96 economic entities that provide public transport services in the two counties. This large number of operators represent a downside for the PT provision, making it very fragmented and difficult to manage, because different operators come with different type of buses that are difficult to identify and differentiate from other transport vehicles. Also, there is not a proper price policy, even though it is stated that the competition brings better prices for the population. Another downside of the large number of PT operators is that they set-up private bus terminals, often in peripheral areas of the cities, or the opposite, in the centre of the city, making the supply very uneven and unattractive. While it is recognized that "terminals may be points of interchange within the same modal system and which ensure a continuity of the flows" (Rodrigue and Slack 2013: 128) and if the terminals for different routes are in different parts of the city, this situation creates an important barrier in the movement of passengers - in Botosani and Suceava cities that is exactly the case, as many firms that ensure county and regional PT are located in different parts of the city.

The supply of road PT in the studied area covers almost the entire area, but there are still some settlements, all rural, that suffer from a lack of this public utility service (Fig. 5), the closest transport station being a couple of kilometres away. The stats in Table 1 show that 10 villages that have a total of 3711 inhabitants (in 2011), from both metropolitan areas, do not have direct access to PT, which means that they have very difficult access to vital services that can be found only in the city. Almost 4000 people suffer from a low supply of PT; the

The number of people affected by the lack or low supply of PT services

Table 2

\begin{tabular}{|c|c|}
\hline Population without PT access & Share of rural population \\
\hline 3711 inhabitants & $3.58 \%$ \\
\hline Settlements without PT access & Share of total rural settlements \\
11 & Share of rural population \\
Population with <4 daily PT routes & $3.78 \%$ \\
\hline 3918 inhabitants & Share of total rural settlements \\
\hline Settlements with <4 daily PT routes & $7.44 \%$ \\
\hline 7 &
\end{tabular}


settlements where they live are transited less than 4 times per day by a bus or a mini-bus, which means that the tracking time is more than 3 and a half hours between the buses.

The numbers of people that do not have direct access or that have low frequency rates is not so high, but in an urban area that wants to be the most competitive at the regional level, having more than $7 \%$ of the rural population makes it an issue that must be tackled with.

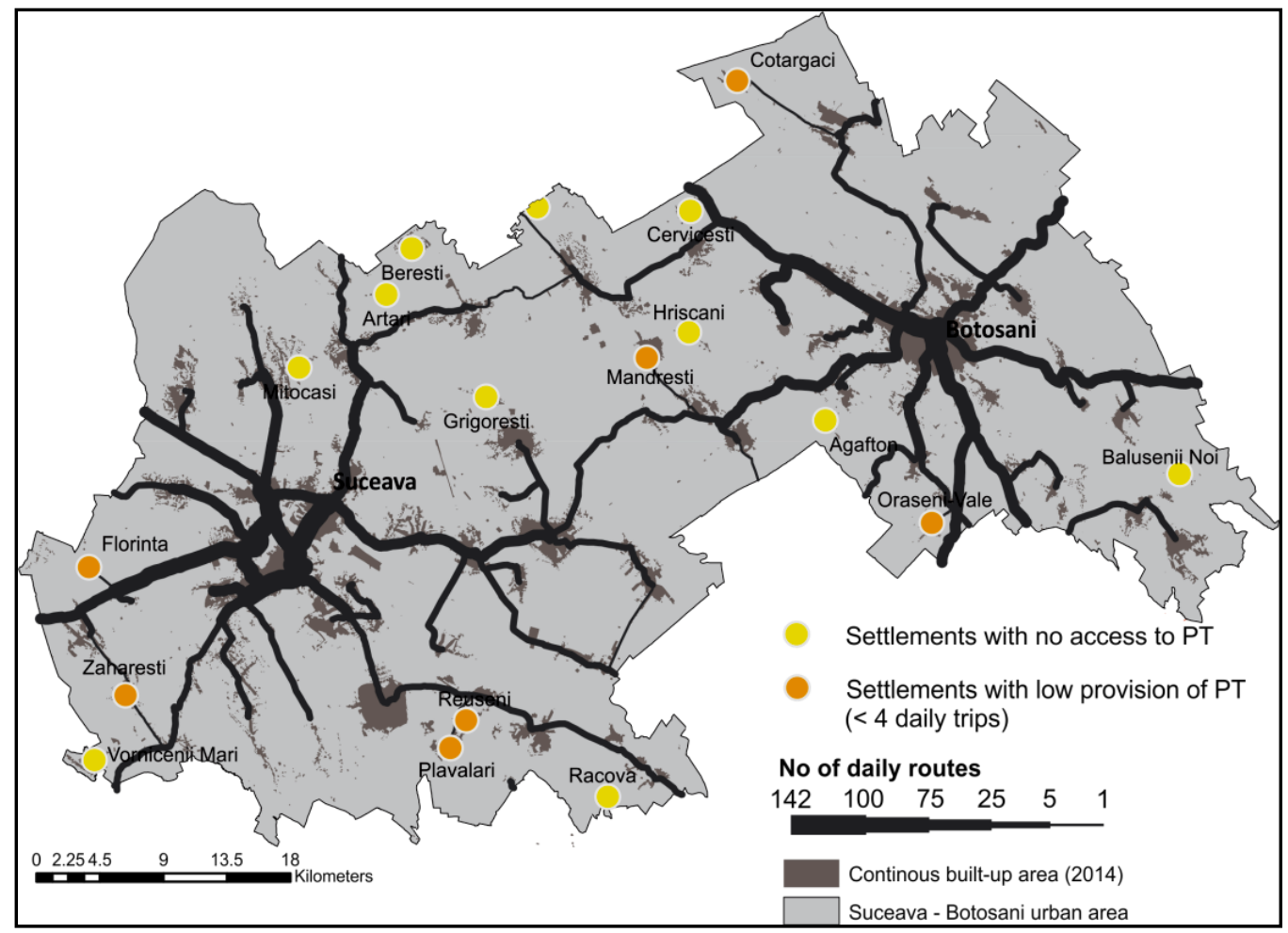

Fig. 5 - The geographic distribution of the rural settlements with lack or low supply of public transportation

The rail passenger transport has different characteristics, due to its dependence on expensive infrastructure and its role of linking nodes across long distances, but in many cases the regional trains (called Regio) have their role in providing public transport services for people who travel on short distances and that use this service for commuting, making a city or a village more accessible. The Suceava-Botoșani Urban Area does not have a railway system dedicated to the local and metropolitan PT like the S-Bahn (in German cities and in Austria's capital, Vienna), S-Tog (in Copenhagen) or the RER network in Paris (Dicembre and Ricci 2011).

The studied area is transited by one rail corridor (500) with 3 branches (502, 511 and 513), that links the Romanian capital, Bucharest, with the Vicșani rail border crossing with Ukraine. The rail density of the studied area is $80 \mathrm{~km} / 1000 \mathrm{~km}$, which is double than the average value for Romania while this number includes also the segments of railway that are outside the administrative borders of Suceava-Botoșani Urban Area (Fig. 6). 


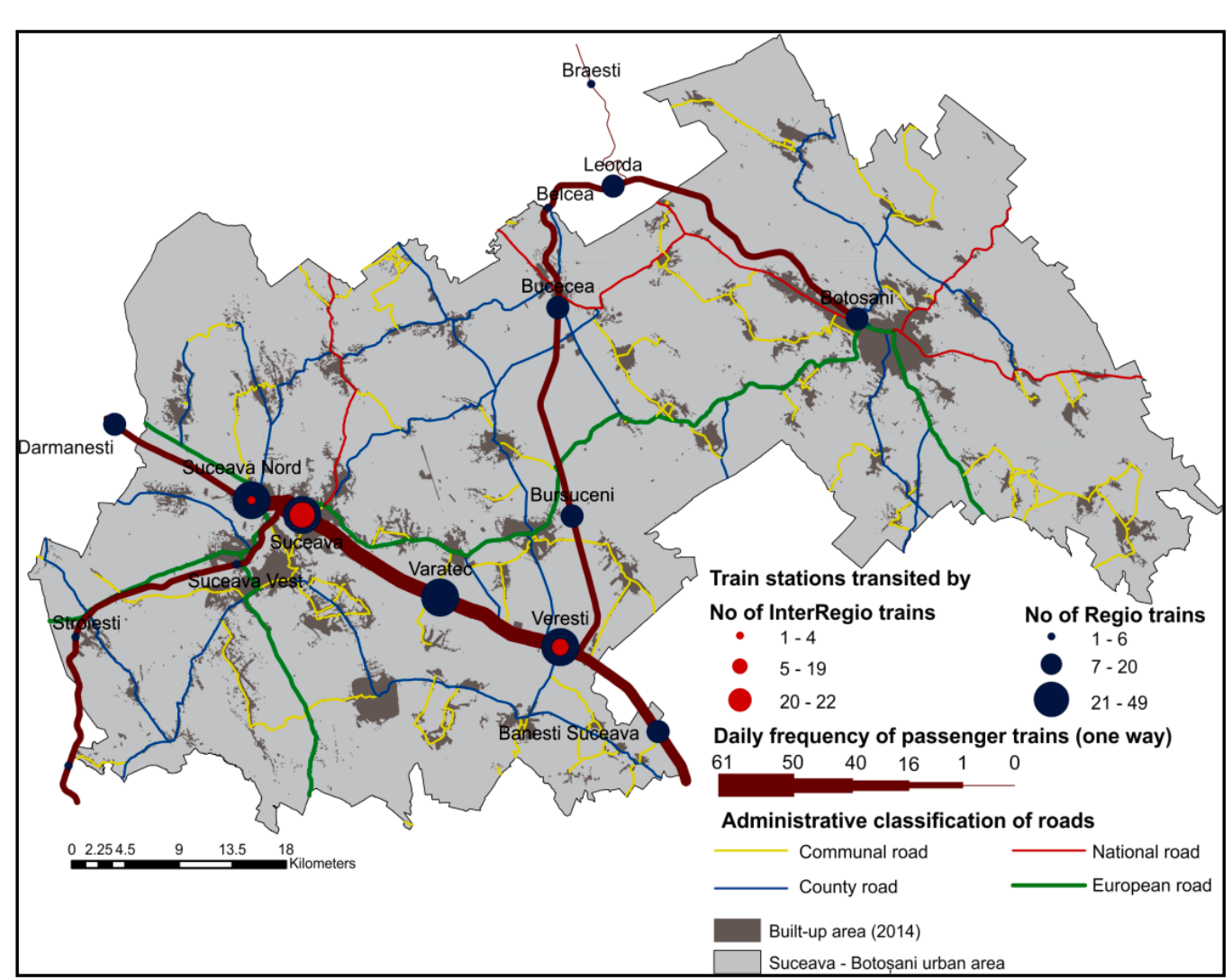

Fig. 6-The geographical distribution and the train daily frequency on the rail network in Suceava-Botoșani Urban Area

Figure 6 shows that the most transited route is the main rail corridor which links Suceava with other important cities in Romania and that Botoșani is a "cul-de-sac" when it comes to rail connectivity, being served by a secondary line. The daily train frequencies are not very high on the secondary lines, as only 14 trains connect Botoșani to its main rail hub, Verești, where the passengers can change trains for other destinations. Except for the mentioned hub, the stations that assure provision for the rural settlements are transited only by Regio trains, because of the transport costs and the low density of population and jobs in these areas (Kilkenny 1998). But the daily frequency is not that high, only the main rail corridor offering enough daily trains that can bring passengers while staying competitive with the road PT. The rail $\mathrm{PT}$ is less competitive than the road $\mathrm{PT}$ even when it comes to costs, the average price per kilometre on road PT being 25 bani (approx. 0.06 euro) while for rail it is 35 bani/km (approx. 0.08 euro). For short distances and for commuting purposes, that imply trips twice a day or twice a week, these price ranges are too high (Oum et al. 1992). But the rail national company offers great discounts for subscribers and for certain social categories like pupils and students that use the train to commute for educational services (Lupchian 2008), Suceava being a university city. 
A long rail distance that is covered in a large amount of time is the cause of the few direct links between the two cores of the studied area. Only 4 direct trains link Suceava to Botosani and the 59 kilometres distance is made in an average time of 1 hour and 40 minutes which makes this route to be unattractive and uncompetitive, determining every commuter to choose other mode of travel (Balcombe et al. 2004).

The main competitor for the both analysed modes of public transport are the private-car travels - the increased mobility that this transport option offers and its comfort makes it more and more used, even in areas where the economic power of the population is not very high (Gwilliam 2010). The growing investments in road infrastructure in Suceava-Botoșani Urban Area determined large cohorts of the population to buy cars, even in rural areas, which suffered massive transformations of their morphology, as the urban sprawl is a present phenomenon (Istrate 2015). The Romanian case confirms the other studies' findings: "For many decades, public transport has been struggling to compete with the auto-mobile. Around the world, the rates of car ownership have been increasing as incomes rise and cars become more affordable. The continuing decentralization of cities into suburban and exurban areas has generated land-use patterns and trips that are difficult for public transport systems to serve" (Buhler and Pucher 2012: 541).

In Botoșani and in Suceava counties the motorization rate has increased. Figure 7 shows the motorization rate in the interval of 2002-2014 at county level. Data for the lower scale are not publicly available, but these time series offer a good picture, as the motorization rate practically doubled for both counties. Suceava County has a higher value for this index due to its higher economic power, but the trend is ascendant and here the increasing motorization index comes with all its perks: better accessibility to services and jobs, increased mobility; but also with its downsides: congestion, social segregation, environmental degradation and a higher share of income spent on commuting (Low 2003, Lucas 2004). Despite this major increase, in these two counties the motorization index is much lower than the Romanian average (235 vehicles/1000

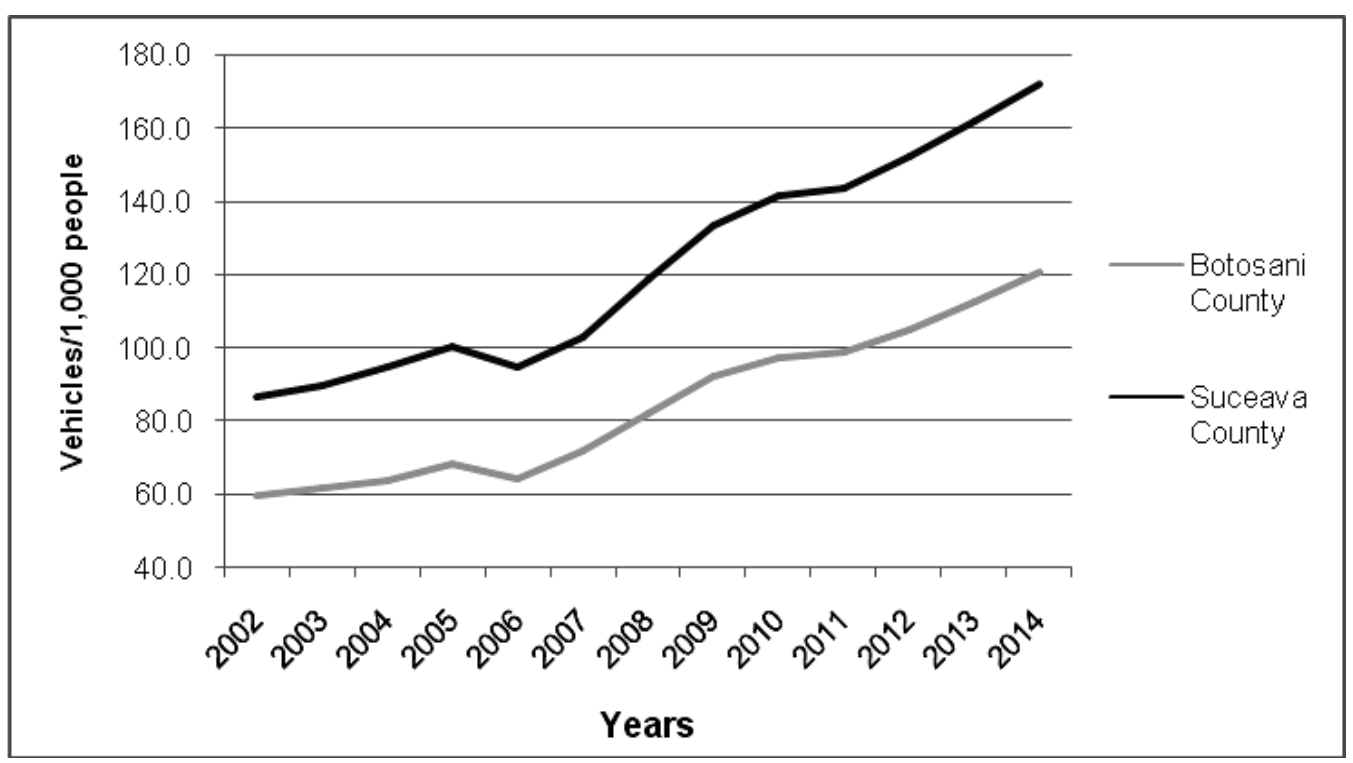

Fig. 7 - Motorization index between 2002-2014 for Suceava and Botoșani Counties Source: DRPCIV, Ministry of Foreign Affairs 
people in 2013, National Institute of Statistics), and the European average (490 vehicles/1000 people in 2013, according to Eurostat).

A high rate of car ownership provides better mobility for those who afford to buy a car but it creates competition and it attracts consumers from the public transport, which can produce a drop in the supply of PT, as a result of smaller demand. The supply can be affected in terms of daily frequencies, capacity and higher prices and in some cases, low-density settlements can be deprived of this public utility service.

\section{Conclusions}

Beyond its intrinsic value for the economy, the transport sector has its role in the activities that people have in their everyday life. Public transport has a great role to create higher accessibility for cities and their metropolitan regions. The supply of PT services is in tight correlation with the demand, but it is not always capable of capturing the population's needs. It is the case of PT services in the studied area, whose planners have not created a framework for a metropolitan road PT or a complementary network together with the rail PT. The publicly available data for road PT make this field of research very valuable for understanding the flow of people between cities and how the big cities are interacting with their hinterland by PT.

Constituted in 2013, the Suceava-Botoșani Urban Area still does not work as a single region when it comes to PT, and it still works as a core and periphery, only that in this case we have two cores and two peripheries. The links between the settlements of the two metropolitan areas are still few and the frequencies are not high enough. The metropolitan facet of the road PT is in a better situation, providing high daily frequencies, especially at $A M$ and PM peaks and it also covers all the cities and the large majority of the villages. As in rail PT, most of the routes offer PT provision for the metropolitan region only as a happening, as they were not planned to provide exclusive services for these areas, and this situation must be worked on.

An analysis of the services quality is difficult to make without a proof methodology and a thorough field research, but this type of assessment can provide proper answers to the rationality between modal shares in the passengers' transport in the studied area.

The social importance of the PT in an area with a low motorization index must bring public transport policies as a priority for those in charge with this domain. In order to provide better services and to have a better geographic coverage, major investments must be done and the system of public auctions must be modified. The actions that will improve the provision of PT, including its road component, must target the creation of one or maximum two bus terminals for the two major urban centres, located in strategic areas, like near the train station, where they can provide passengers one to another, or major hub of the urban public transport network, and all the existing private bus terminals must be displaced there, in order to have a single hub for the county, metropolitan and regional PT.

The planning of the PT must be improved. Without quantitative and qualitative data, a proper diagnosis, that should offer a clear image of the entire PT system, is difficult to establish. A better collaboration between the network's planners is required. The towns' and villages' public authorities can ask for certain updates to the existing supply and because they know better the demand at local level, they should get more involved in this process. Also, even though the routes are granted by the county's council, the stations in each locality are in the local authorities' backyard and the location and the conditions for waiting the bus must be improved and the timetable displayed in every station. A method to have fewer companies that win these auctions must be implemented. The fragmentation of the routes is a bad strategy because in this manner the cash flow entries are low and the transport companies do not have the 
financial power to buy newer, high capacity buses, that offer better comfort to the passengers and they will always be tempted to take passengers over capacity and to not offer tickets, which leads to a reorientation of the passengers for private cars.

It is mandatory that new routes to be established, in order to offer PT services for the population that suffers from a lack of PT supply. Also, more direct links, even some express ones, between Suceava and Botoșani cities are imposed, while, on this route, the competition between the PT and private cars is fierce and there is room for a better transport with low investments. The road infrastructure must be improved, in order for the PT operators to stay competitive, to optimize the expenses of the firms and to lower the times for PT. This recommendation is quite difficult to implement by reasons of high costs and different infrastructure owners, that do not always collaborate.

For the rail PT, the situation is more difficult, as the expensive investments that must be made to optimize the speed and the offered comfort are determining that a better supply of this service to be difficult to obtain. Besides the investments in heavy infrastructure and signalling (Dicembre and Ricci 2011), the rolling stock must be optimized for regional passenger transport and for different type of track, hybrid trains being the most recommendable. Some soft actions still can be done, like setting new stations for Regio trains near the dense built-up areas and improved local access to these stations among their modernization, but until the rail PT will not offer lower travel times to its passengers, the demand and the supply for such services will be still low for short distances.

The relevance of this paper's findings is that based on this framework regarding the provision of PT, the authorities can take better decisions using the GIS software by simply displaying the main attributes of PT provision. This tool can easily be used by other decision makers in this field of activity, in other metropolitan areas in Romania that want to increase the synergies between the core cities and the settlements around them. Improvements of the PT services are vital for the sustainable developments of the city, as the spatial planning of the cities and their metropolitan areas must take into account the PT networks in order to provide access to jobs and general interest services to a broader range of population. The decline of this part of transportation in the last two decades can be ameliorated with better and flexible services. For Botosani and Suceava cities, this approach can lead to a better collaboration between them and to an increase of flows from which both can benefit. The development of the supply of PT can create strong connections between the urban centres and their metropolitan areas, gaining a more important role for their hinterland.

\section{References}

ABUNDO C., BODNAR T., DRISCOLL J., HATTON I., WRIGHT J. (2013), City population dynamics and fractal transport networks, Proceedings of the Santa Fe Institute's Complex Systems Summer School, 1-7.

AMARAL M., SAUSSIER S., YVRANDE-BILLON A. (2009), Auction procedures and competition in public services: The case of urban public transport in France and London, Utilities Policy 17 (2), 166-175.

BALCOMBE R. (ed.), MACKETT R., PAULLEY N., PRESTON J., SHIRES J., TITHERIDGE H., WARDMAN M., WHITE P. (2004), The demand for public transport: a practical guide, TRL Limited, Wokingham.

BOTOȘANI COUNTY COUNCIL (2015), Socio-Economic Development Strategy of Botoșani County for 2014-2020 (in Romanian), Available at: http://www.cjbotosani.ro/portal/ files/h043_27.03.2014.pdf.

BRESSON G., DARGAY J. MADRE J.-L., PIROTTE A. (2004), Economic and structural determinants of the demand for public transport: an analysis on a panel of French urban areas 
using shrinkage estimators, Transportation Research Part A: Policy and Practice 38 (4), 269285 .

BUEHLER R., PUCHER J. (2012), Demand for Public Transport in Germany and the USA: An Analysis of Rider Characteristics, Transport Reviews 32 (5), 541-567.

DICEMBRE A., RICCI S. (2011), Railway traffic on high density urban corridors: Capacity, signalling and timetable, Journal of Rail Transport Planning \& Management 1 (2), 5968.

ESPON (2004), Transport services and networks: territorial trends and basic supply of infrastructure for territorial cohesion, ESPON Project 1.2.1, Project report, Luxembourg.

FISTUNG F. D., MIROIU R., TĂTARU D., IȘTOC M., POPESCU T. (2014), Transport in support of the process of socio-economic development of Romania, after 1990, Procedia Economics and Finance 8, 313-319.

GWILLIAM K. (2003), Urban transport in developing countries, Transport Reviews 23 (2), 197-216

IORDACHE C. (2009), The Evolution of the Urban Public Transport During The 19502006 Period in Romania, Forum Geografic 8 (8), 108-115.

ISTRATE M. I. (2015), Urban Sprawl and Demographic Dynamics In Suceava Metropolitan Area, Journal of Community Positive Practices 2, 43-55.

JANNSON K. (1993), Swedish Competitive Tendering in Local and Regional Public

Transport: Overview and Comparative Case Studies, Thredbo 3 Conference, 243-262.

KANAFKANI A. K. (1983), Transportation Demand Analysis, McGraw-Hill, New York.

KILKENNY M. (1998), Transport costs, the new economic geography, and rural development, Growth and change 29, 259-280.

LOW N. (2003), Is urban transport sustainable?, in: Low N., Gleeson B. (eds.), Making

Urban Transport Sustainable, Palgrave Macmillan, New York, pp. 1-21.

LUCAS K. (2004), Transport and social exclusion, in: Lucas K. (ed.), Running on Empty:

Transport, social exclusion and environmental justice, The Policy Press, Bristol, pp. 39-53.

LUPCHIAN M. M. (2008), Des déplacements journaliers pour l'école dans la ville de Suceava, Georeview 17, 183-190.

MURRAY A. T. (2001), Strategic analysis of public transport coverage, Socio-Economic Planning Sciences 35 (3), 175-188.

NATIONAL INSTITUTE OF STATISTICS (2013), Repere economice şi sociale regionale: Statistică teritorială, INS, Bucharest.

ONG P., BLUMENBERG E. (1998), Job Access, Commute and Travel Burden Among Welfare Recipients, Urban Studies 35 (1), 77-93.

OUM T. H., WATERS W. G., YONG J.-S. (1992), Concepts of Price Elasticities of Transport Demand and Recent Empirical Estimates: An Interpretative Survey, Journal of Transport Economics and Policy 26 (2), 139-154.

PAIN K. (2008), Examining 'Core-Periphery' Relationships in a Global City-Region: The

Case of London and South East England, Regional Studies 42 (8), 1161-1172.

PINJARI A. R., BHAT C. R. (2011), Activity-based travel demand analysis, in: de Palma

A., Lindsey R., Quinet E., Vickerman R., A Handbook of Transport Economics, Edward Elgar Publishing Limited, Cheltenham, pp. 213-248.

RÄDULESCU V., STRĂINESCU I., MOROIANU L., TUDOR E., GOIA C., BOZAȘ F.,

LUPU V., RĂDULESCU B., TĂNASE M. (2013), The need to improve transport conditions in the big cities of Romania, Urban Transport XIX, 125. RODRIGUE J. P., SLACK B. (2013), The function of transport terminals, in: Rodrigue J. P., Comtois C., Slack B. (eds.), The Geography of transport systems, Routledge, Third Edition, New York, pp. 127-134.

ROTEM-MINDALI O., GEFEN D. (2014), Rail Transportation and Core-Periphery

Reliance in Israel, Journal of Urban and Regional Analysis 6 (2), 113-127.

SANCHEZ T. W., SHEN Q., PENG Z.-R. (2004), Transit Mobility, Jobs Access and Low

-income Labour Participation in US Metropolitan Areas, Urban Studies 41 (7), 1313-1331.

von FERBER C., HOLOVATCH T., HOLOVATCH Y., PALCHYKOV V. (2009), Public 
Transport Networks: Empirical analysis and modeling, The European Physical Journal B 68 (2), 261-275.

Initial submission: 26.11.2015

Revised submission: 18.05.2016

Final acceptance: 07.06.2016

Correspondence: "Simion Mehedinti" Doctoral School, Faculty of Geography, University of Bucharest, 1 Nicolae Balcescu Blv., 010041, Sector 1, Bucharest, Romania.

E-mail: istratemarianionut@yahoo.fr 
